\title{
Zygosporium chinensis-A new foliicolous species infecting Litchi chinensis in Chhattisgarh, India
}

\author{
Anshu Deep Khalkho*, Smriti Bhardwaj, Anurag Dubey, Shikha Jain and Akhila Nand Rai \\ Department of Botany, Dr. Hari Singh Gour Vishwavidyalaya, Sagar, M.P.-470003, India \\ *Corresponding author Email: anshudeepxalxo18@gmail.com \\ (Submitted on March 20, 2020 ; Accepted on May 29,2020)
}

\begin{abstract}
During the survey of protected forest areas of Ambikapur in north Chhattisgarh in India for foliicolous fungi during the month of January 2018 , an interesting fungal form was found infecting both attached living and dried leaves of Litchi chinensis Sonn. Based on phenotypic, microscopic, SEM based investigations and comparison with other allied taxa a new species of Zygosporium Mont. namely Zygosporium chinensis has been described. The new species shows difference in setiform conidiophore septation.
\end{abstract}

Keywords: Foliicolous, hyphomycetous, Litchi chinensis, SEM, Zygosporium

\section{INTRODUCTION}

During the survey of Ambikapur forested area a large number of fungal forms were collected on medicinally and economically important plants and one of them was Litchi chinensis Sonn., belonging to family Sapindaceae. It is a well known economically important fruit plant with variety of medicinal uses (Kilari and Putta, 2016). During the survey it was observed that fungal infection in the plant starts from tip of the leaf and finally covering it entirely. All such infected leaves start drying in due course which are then shed off from the parent plant after they have completely dried. Due to the severe fungal infection on the foliage the fruit size and the yield as a consequence reduces appreciably. Thirty species of Zygosporium Mont. (www.mycobank.org; www.index fungorum.org) are reported so far from all over the world. As compared only five species of this genus (www.myco bank.org, www.indexfungorum.org), namely Z. anupamvarmae Manoharachary, D.K. Agarwal, Suresh Kumar, Sharanth \& Kunwar (Manoharachary et al., 2006), Z. cocos Rashmi Dubey (Dubey, 2014), Z. dilleniae Rashmi Dubey (Dubey, 2014), Z. tuberculatum Subramanian \& Bhat (Subramanian and Bhat, 1987) and Z. verticillatum S.B. Thakur \& Udipi (Thakur and Udipi, 1976 ) are documented from India. When the cause of the infection was studied using the microscopic and SEM based investigations, the both living and dried leaves were found infected by a hyphomycetous fungus Zygosporium. The diagnostic features of this taxon were quite unique based upon which a new species $Z$. chinensis sp. nov. is being described.

The genus Zygosporium is characterized by thin to effuse, grey to black colonies, setiform conidiophores macronematous, smooth, swollen, curved dark brown single vesicle from setiform conidiophore, upper part terminating in a knob, conodiogenous cell monoblastic, ampulliform, conidia developing from conidiogenous cells, hyaline to brown, smooth to verruculose. (Ellis, 1971)

\section{MATERIALSAND METHODS}

Infected leaves were collected from study area, into clean polythene bags with information tags tied i.e area, date of collection, location, and plant identification. A detailed information was maintained in a note book. Samples were properly dried and pressed in blotting paper. Samples showing fungal lesions were scratched on to a slide, mounted with lactophenol + cotton blue and a coverslip was carefully placed for slide preparation (Dubey et al., 2019). For detailed study of the morphological features, the microscopic observations were made under an Olympus CX21i Trinocular light microscope and images were captured by MIcap. Micrometry of conidiophores and conidia were recorded at $400 \mathrm{X}$ magnification. For detailed investigations scanning electron microscope (SEM) was used. Because of being dried the samples could not be given the preparative treatment for undertaking SEM studies (Bhardwaj et al., 2019). The specimens were coated with a thin layer of gold-palladium using Denton Vacuum and examined using NOVA NANO SEM 450. The holotype of the specimen (AMH-10051) has been deposited in Ajrekar Mycological Herbarium (AMH), Agharkar Research Institute Pune, India and an isotype at RA Herbarium (RAH), Botany Department Dr. Hari Singh Gour Vishwavidyalaya, Sagar, M. P. India.

\section{TAXONOMIC DETAILS}

Zygosporium chinensis A.D. Khalkho, S. Bhardwaj, A. Dubey, S. Jain \& A.N. Rai, sp. nov.

Figs. 1 \& 2.

\section{Mycobank No.: MB 834791}

Etymology: The epithet refers to the host species name.

Diagnosis: The newly described species Zygosporium chinensis (Holotype: AMH-10051) differs from the other Zygosporium species by its symptomatology, nature, dimensions of setiform conidiophores, vesicular conidiophores, conidia and septation in setiform conidiophores which is of rare occurrence.

Taxonomic description: Leaf lesions initiating from tip, amphigenous, small to large, irregular. Colony hyphophyllous, dark brown to black, colony present in all infected portions. Mycelium immersed. Conidiophores macronematous, scattered, unbranched or dichotomously branched, straight to flexuous, subulate, brown, smooth, 36$56 \times 2.5-3 \mu \mathrm{m}$., bearing a single vesicle, sterile, setiform, upper part terminating in a knob, slightly swollen, curved vesicle $9-18.5 \times 6-11.5 \mu \mathrm{m}$., dark brown, aseptate or singly septate. Conidiogenous cells monoblastic, ampliform, dark brown. Conidia solitary, acrogenous, simple spherical or ellipsoidal, hyaline to pale brown, smooth to verruculose, 4.9 $-6.4 \times 3.5-5 \mu \mathrm{m}$. 

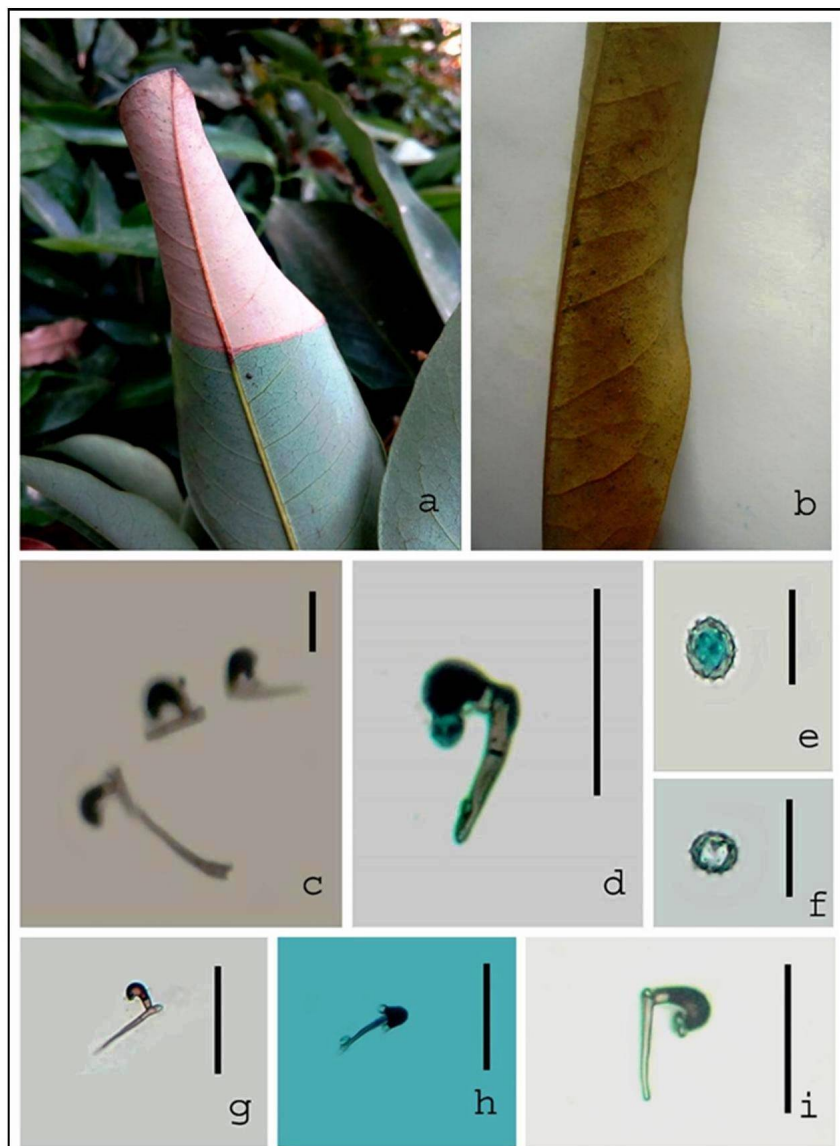

d
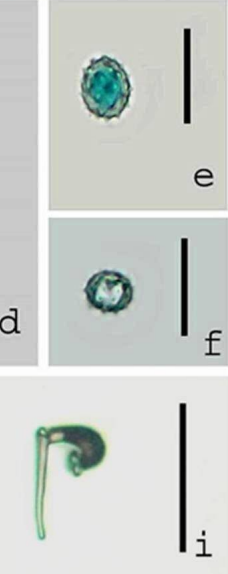

Fig. 1 Zygosporium chinensis: (a). Symptoms on healthy leaves, (b). Symptoms on dry leaves, (c). Setiform conidiophores, (d). Attachment of conidium with setiform conidiophore, (g). Single setiform conidiophore. (h-i). Setiform conidiophore with conidia (e-f). Conidia. Scale: (c,d,g,h,i). $20 \mu \mathrm{m}$. (E-f). $10 \mu \mathrm{m}$.
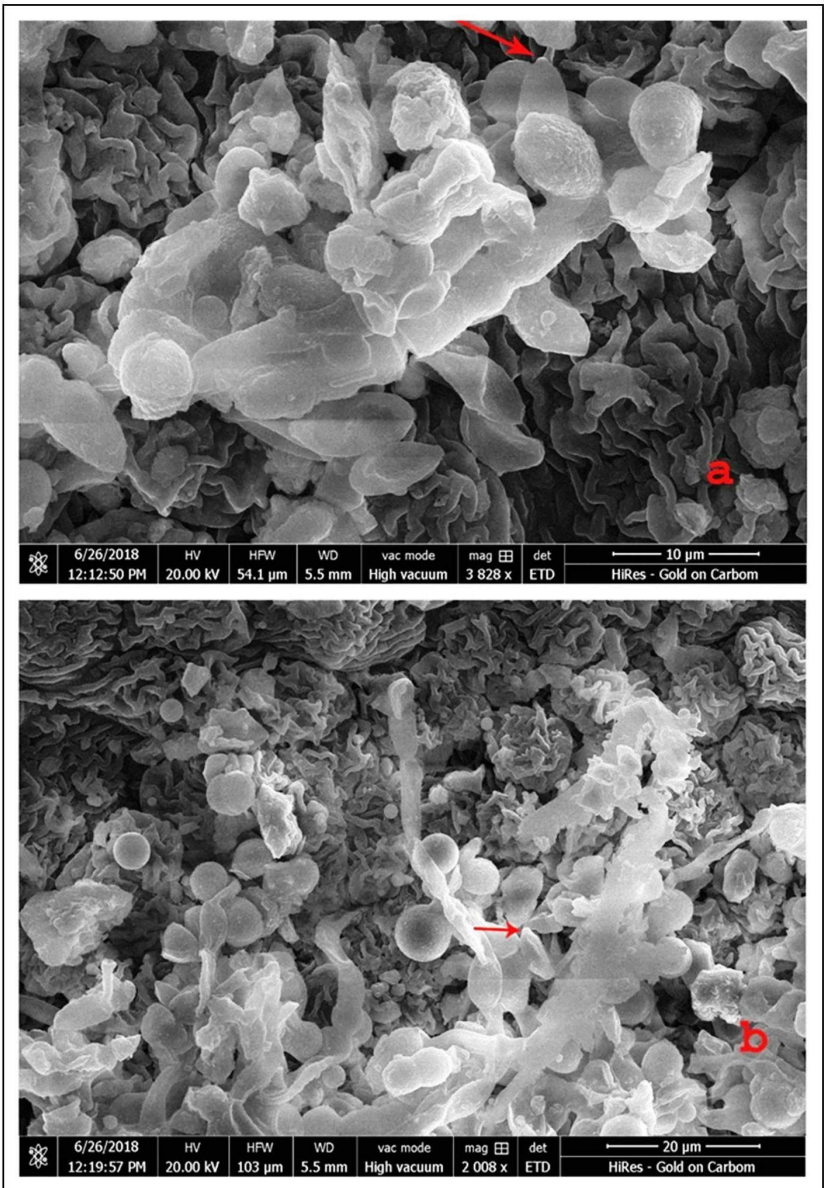

Fig. 2 Zygosporium chinensis: SEM images (a-b). Conidium with scar. Conidium at 3,828X and 2008X magnification, respectively.

Table 1: Comparative account of Litchi chinensis sp. nov. with similar taxa in the genus

\begin{tabular}{|c|c|c|c|c|c|c|c|c|}
\hline \multirow[t]{2}{*}{ Species } & \multirow{2}{*}{$\begin{array}{l}\text { Leaf spots and } \\
\text { colonies }\end{array}$} & \multicolumn{3}{|c|}{ Setiform conidiophore } & \multicolumn{2}{|c|}{ Vesic ular conidiophore } & \multicolumn{2}{|l|}{ Conidia } \\
\hline & & Structure & $\begin{array}{l}\text { Colour \& } \\
\text { septation }\end{array}$ & $\begin{array}{c}\text { Size in } \\
(\mu \mathrm{m})\end{array}$ & $\begin{array}{c}\text { Structure \& } \\
\text { Colour }\end{array}$ & $\begin{array}{l}\text { Size in } \\
(\mu \mathrm{m})\end{array}$ & $\begin{array}{c}\text { Structure \& } \\
\text { Colour }\end{array}$ & $\begin{array}{c}\text { Size in } \\
(\mu \mathrm{m})\end{array}$ \\
\hline $\begin{array}{c}\text { Zygosporium } \\
\text { oscheoides } \\
\text { Mont. (Ellis, } \\
1971 \text { ) }\end{array}$ & $\begin{array}{c}\text { On decaying } \\
\text { leaves, effuse to } \\
\text { compact }\end{array}$ & Subulate & $3-4$ & $80 \times 3-4$ & 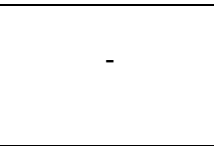 & $9-18 \times 7-9$ & $\begin{array}{l}\text { Ellipsoid,smooth to } \\
\text { minutely } \\
\text { verruculose, hyaline } \\
\text { to pale brown }\end{array}$ & $\begin{array}{c}7- \\
12.5 \times 4-9\end{array}$ \\
\hline $\begin{array}{l}\text { Z. pandanicola } \\
\text { (Whitton et } \\
\text { al., 2003) }\end{array}$ & $\begin{array}{c}\text { On decaying } \\
\text { leaves, effuse to } \\
\text { compact }\end{array}$ & $\begin{array}{c}\text { Clavate and } \\
\text { smooth at } \\
\text { the apex }\end{array}$ & $\begin{array}{c}\text { Hyaline to } \\
\text { dark brown, } \\
3-4\end{array}$ & $\begin{array}{r}67-86 \\
\times 4-5.5\end{array}$ & $\begin{array}{c}\text { Cylindrical, dark } \\
\text { brown }\end{array}$ & $\begin{array}{l}15.5-16 \times \\
8.5-9\end{array}$ & $\begin{array}{l}\text { Spherical, } \\
\text { tuberculate to } \\
\text { capitate, raised } \\
\text { areas flattened, } \\
\text { brown }\end{array}$ & $11-14.5$ \\
\hline $\begin{array}{c}\text { Z. bioblitzi } \\
\text { (McKenzie et } \\
\text { al., 2007) }\end{array}$ & $\begin{array}{l}\text { On dead leaves, } \\
\text { effuse to compact }\end{array}$ & Subulate & Brown, 3 & $\begin{array}{c}40- \\
75 \times 2-3\end{array}$ & $\begin{array}{l}\text { Circular, } \\
\text { cylindrical, } \\
\text { brown }\end{array}$ & $\begin{array}{c}8- \\
10.5 \times 3.5- \\
5.5\end{array}$ & $\begin{array}{c}\text { Ellipsoidal to oval, } \\
\text { brown }\end{array}$ & $\begin{array}{l}14- \\
21 \times 7.5- \\
11\end{array}$ \\
\hline $\begin{array}{l}\text { Z. chinensis } \\
\text { sp. nov. }\end{array}$ & $\begin{array}{l}\text { Healthy \& dry } \\
\text { leaves, } \\
\text { hyphophyllous, } \\
\text { brown to black }\end{array}$ & Subulate & Brown, 0-1 & $\begin{array}{c}36- \\
56 \times 2.5-3\end{array}$ & $\begin{array}{c}\text { Circular, } \\
\text { cylindrical, dark } \\
\text { brown }\end{array}$ & $\begin{array}{l}9-18.5 \times 6- \\
11.5\end{array}$ & $\begin{array}{c}\text { Ellipsoidal to } \\
\text { spherical, hyaline to } \\
\text { pale brown }\end{array}$ & $\begin{array}{c}4.5- \\
6.4 \times 3.5-5\end{array}$ \\
\hline
\end{tabular}


Specimen examined: On living and dried but attached leaves of Litchi chinensis (Sapindaceae), from Ambikapur (Chhattisgarh) India, January 2018, leg. Anshu Deep Khalkho (Holotype AMH-10051; Isotype RAH Herbarium- 83).

\section{DISCUSSION}

The new species Zygosporium chinensis is morphologically different from previously described species of Zygosporium. Some of its closely allied species includes $Z$. oscheoides Mont. (Ellis, 1971), Z. pandanicola Whitton, McKenzie \& K.D. Hyde (Whitton et al., 2003), Z. pacificum Whitton, McKenzie \& K.D. Hyde (Whitton et al., 2003), Z. bioblitzi Mckenzie, Thongk. \& Lumyong (McKenzie et al., 2007) and Z. geminatum San-Blas, Moreno, Calcagno \& San-Blas (SanBlas et al., 1998) but latter shows a distinct septate setiform conidiophore with smaller vesicular conidiophore and conidia as compared to other species (Table 1). Literature survey reveals that no species of Zygosporium has previously been reported on Litchi chinensis Sonn. (https://nt.arsgrin.gov/fungaldatabases/). In view of the significant differences with the already known species of Zygosporium and uniqueness, $Z$. chinensis sp. nov. is proposed to accommodate the presently examined fungus infecting Litchi chinensis in the forests of Chhattisgarh.

\section{ACKNOWLEDGEMENTS}

The authors would like to thank the Curator (AMH), Agharkar Research Institute (ARI), Pune, Maharashtra, India for giving accession number of fungal sample and deposition. Dr Hari Singh Gour Vishwavidyalaya for access to Nova Nano SEM 450. Authors are also thankful to the Head, Department of Botany, Dr. Hari Singh Gour Vishwavidyalaya, Sagar M.P., for providing laboratory facilities. This work was financially supported by Ministry of Tribal Affairs, Govt of India.

\section{REFERENCES}

Bhardwaj, S., Thakur, R.S. and Rai, A.N., 2019. Gyrothrix kigeliae: A novel setose fungus from Central India. Kavaka 53: 82-84.
Dubey, R. 2014. Two new species of Zygosporium Mont. from Indian subcontinent. Indian J Forest 37 (2): 165-168.

Dubey, A., Bhardwaj, S., Pandey, A.K., Khalkho, A.D., Jain, $\mathrm{S}$ and Rai, A. 2019. Anew species of Acremoniula $\mathrm{G}$. Arnaud ex CIF. on Butea Monosperma (Lam.) Taub.-An important medicinal plant from forest flora of Jashpur (C.G.). Journal of Experimental Biology and Agricultural Sciences 7(6): 600-605.

Ellis, M.B. 1971. Dematiaceous Hyphomycetes. CMI, Kew, England,pp. 322-324.

Kilari, E.K. and Putta, S., 2016. Biological and phytopharmacological descriptions of Litchi chinensis. Pharmacognosy reviews 10 (19): 60.

Manoharachary, C., Agarwal, D. K., Sureshkumar, G., Kunwar, I. K., and Babu, K. S. 2006. Memnoniella mohanramii sp. nov. and Zygosporium anupamvarmae $\mathrm{sp}$. nov. from India. Indian Phytopathology 59: $(4,489$.

McKenzie, E.H.C., Thongkantha, S. and Lumyong, S., 2007. Zygosporium bioblitzi sp. nov. on dead leaves of Cortaderia and Dracaena. New Zealand Journal of Botany 45 (2): 433-435.

San-Blas, G., Moreno, B., Calcagno, A.M. and San-Blas, F., 1998. Lysis of Paracoccidioides brasiliensis by Zygosporium geminatum. Medical Mycology $\mathbf{3 6}$ (2):75-79.

Subramanian, C.V. and Bhat, D.J. 1987. Hyphomycetes from South India I. Some new taxa. Kavaka 15: 41-74.

Thakur, S.B. and Udipi, P.A. 1976. Zygosporium verticillatum sp. nov. from marine habitat. Kavaka B: 59-60.

Whitton, S.R., McKenzie, E.H. and Hyde, K.D., 2003. Microfungi on the Pandanaceae: Zygosporium, a review of the genus and two new species. Fungal Diversity 12: 207-222. 